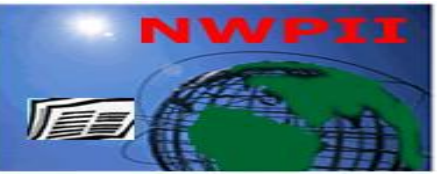

American Journal of Biomedical Sciences

ISSN: 1937-9080

nwpii.com/ajbms

\title{
Study of Visfatin Level and Its Relation to Some Histopathological Changes of Placentae in Preeclampsia
}

\author{
M.A.Megahed ${ }^{1}$, S.M.Dawoud ${ }^{1}$, A.I.El-Sarha ${ }^{2}$, M.A.Fayed ${ }^{1}$, and M.I.Ahmed ${ }^{3}$
}

${ }^{1}$ Biochemistry Department, Medical Research Institute, Alexandria University, Egypt

${ }^{2}$ Pathology Department, Medical Research Institute, Alexandria University, Egypt

${ }^{3}$ Department of Gynecology and Obstetrics, Faculty of Medicine, Benha University, Egypt

"Corresponding Author

Magda A. Megahed

Medical Research Institute,Alexandria University

165,Elhorreya Avenue, Hadara, Alexandria

Egypt

Tel:+2034282331,+2034282373

Fax:+2034283719

Email:magda.megahad@alexu.edu.eg

Received:22 February 2019; | Revised:20 April 2019; | Accepted:18 August 2019

\section{Abstract}

The objective of the present study was to measure the serum level of visfatin in preeclamptic Egyptian pregnant women and the possible relation of visfatin level to each of the measured insulin resistance, body mass index and histopathological changes of the placenta included in this study.

The study population consisted of 30 preeclamptic patients and 30 matched healthy pregnant women during the third trimester.

The present study results revealed that preeclamptic mothers had a significant increase in insulin resistance value than normal pregnant women with no significant difference in this value between mild and severe preeclamptic sub-groups. Regarding visfatin level, there was a highly significant increase in visfatin level in preeclamptic women compared with healthy controls and also increase in severe than mild preeclamptic sub-groups. Correlation analysis presented a significant negative correlation between maternal visfatin levels versus HOMA-IR among preeclamptic group, but no relation had been found between visfatin levels and body mass index among preeclamptic mothers. Histopathological examination of placentae revealed that infarctions, atherosis, hyalinized areas and Tenny Parkers changes were significantly increased in preeclamptic group than control group. The present study did not find any correlations between visfatin levels versus histopathological changes in placentae among preeclamptic mothers.

Hypervisfatinemia may be one of the possible etiologies of preeclampsia. Visfatin might be part of a feedback mechanism improving insulin sensitivity. Preeclamptic placentae exhibited definite histopathological changes which may be attributed to the vascular insufficiency of placenta.

Keywords: Visfatin, Preeclampsia, Insulin resistance, Placenta, Infarction 


\section{Background}

Preeclampsia (PE), a hypertensive disorder in pregnancy is believed to be one of the leading causes of maternal and fetal morbidity and mortality worldwide ${ }^{[1]}$. It is a classical triad of hypertension, proteinuria and edema, defined as "a new onset of elevated blood pressure of $140 / 90 \mathrm{~mm} \mathrm{Hg}$ or more, recorded on two separate occasions at least 6 hours apart and in the presence of at least $0.3 \mathrm{~g}$ of protein in a 24 hour urine, arising after the $20^{\text {th }}$ week of gestation in a previously normotensive patient, and resolving completely between 6-12 weeks after delivery ${ }^{[2]}$.

In developing nations, the incidence of the disease is reported to be $4-18 \%$, with hypertensive disorders being the second most common obstetric cause of stillbirths and early neonatal deaths in these countries ${ }^{[3]}$. There is compelling evidence that complications of pregnancy such as preeclampsia and intrauterine growth restriction (IUGR) are associated with maternal cardiovascular disease in the future. Both pregnancy disorders are characterized by a disturbed placental function and are associated with insulin resistance ${ }^{[4]}$.

Insulin resistance in pregnancy and preeclampsia is mainly attributed to placental hormones ${ }^{[5]}$ and increased maternal adiposity ${ }^{[6]}$. Adipose tissue represents an active endocrine organ that releases a large number of bioactive mediators (adipokines) that signal to organs of metabolic importance including brain, liver, skeletal muscles and the immune system thereby modulating hemostasis, blood pressure, lipid and glucose metabolism and inflammation. These adipokines include adiponectin, leptin, omentin, resistin, retinol binding protein, tumor necrosis factor- $a$, interleukin-6, vaspin, chemerin and visfatin ${ }^{[7]}$.

Besides regulating maternal energy metabolism and insulin sensitivity in normal pregnancy, adipokines have been implicated in preeclampsia. Increasing number of studies reported the role of these proteins in the deleterious insulin resistance associated with preeclampsia; however, these reports are characterized by some inconsistency and contradictions ${ }^{[8]}$.

A cross sectional study demonstrated that the maternal serum visfatin levels were significantly increased in women with mild preeclampsia and even more increased in women with severe preeclampsia ${ }^{[9]}$. However, the exact opposite was reported by $\mathrm{Hu}$ et al. ${ }^{[10]}$, indicating that further studies are necessary to evaluate the potential role of visfatin as a marker for preeclampsia.

The aim of the present study was to measure the serum level of visfatin in preeclamptic Egyptian pregnant women and the possible relation of visfatin level to each of the measured insulin resistance, body mass index and histopathological changes of the placenta included in this study.

\section{Pateints and Methods}

\subsection{Patients}

This study was conducted in the departments of Obstetrics and Gynecology in Benha, Mansoura Universities Hospitals and Biochemistry Department Medical Research Institute, Alexandria University and included sixty pregnant women. A written and verbal consent has been obtained from all participants in the study according to the Instructions and Guidelines of the Ethics Committee of the Medical Research Institute, Alexandria University. They were divided into two groups:

Group I: Consists of thirty pregnant women with no obstetric or medical complications of pregnancy, no medications were given during pregnancy apart from tonics and iron, single viable pregnancy, Gestational age (37- 40) weeks and spontaneous delivery of the placenta.

Group II: Consists of thirty preeclamptic women diagnosed according to its type as:

Mild preeclampsia: after 20 weeks pregnant women with blood pressure greater than 140 systolic or 90 diastolic, $0.3 \mathrm{~g}$ of protein in 24-hour urine sample or persistent $1+$ protein measurement on urine dipstick and there are no other signs of problems with the mother or the baby.

Severe preeclampsia: after 20 weeks pregnant women with very high blood pressure (greater than 160 systolic or 110 diastolic), greater than $5 \mathrm{~g}$ of protein in a 24-hour sample, very low urine output, signs of central nervous system problems (severe headache, blurry vision, altered mental status), signs of liver problems (nausea and/or vomiting with abdominal pain) ,at least twice the normal measurements of certain liver enzymes on blood test, thrombocytopenia, signs of respiratory 
problems (pulmonary edema, bluish tint to the skin) and severe fetal growth restriction.

Exclusion criteria will include patients with combined chronic diseases e.g, diabetes mellitus, autoimmune disease, thyroid, heart, chest, kidney, liver diseases and patients with preexisting chronic hypertension or taking hormonal replacement.

\subsection{Methods}

All subjects included in this study were asked for complete history (personal, menstrual, obstetrical, past history and drug history) and subjected to clinical and obstetrical examination. During fasting condition, urine and blood samples were collected from each case. Five milliliters blood from each case was taken and allowed to clot for 30 minutes before centrifugation for 15 minutes at $1000 \mathrm{x}$ g. Serum collected and stored in three aliquots at $-20^{\circ} \mathrm{C}$.

Biochemical studies:

1- Proteinuria using urinary albumin creatinine ratio (ACR) that expressed as milligram of albumin excreted per gram of urinary creatinine ${ }^{[11]}$.

Creatinine levels [12]: Quantitative determination of urinary creatinine was performed according to the manufacturer's instructions (Diamond Diagnostics) with detection limit 0.09 $\mathrm{mg} / \mathrm{dL}$.

Albumin levels ${ }^{[13]}$ : Quantitative determination of urinary albumin was measured turbidimetry as to manufacturer's instructions (Biosystems S.A. Costa Brava 30, Barcelona, Spain).

2- Insulin resistance using homeostasis model assessment of insulin resistance (HOMA-IR) ${ }^{[14]}$.

HOMA-IR $=$ fasting insulin $(\mu \mathrm{IU} / \mathrm{mL}) \times$ fasting glucose $(\mathrm{mmo} \Lambda) / 22.5$

Fasting glucose levels [15]: It was measured using enzymatic colorimetric glucose oxidase method (kit purchased from spin react, Spain) with detection limit from $1 \mathrm{mg} / \mathrm{dL}$ to linearity limit 500 $\mathrm{g} / \mathrm{dL}$.

Insulin levels ${ }^{[16]}$ : Concentration of insulin was measured using ELISA method according to the manufacturer's instructions (DRG International Inc., USA, (EIA-2935)).

3- Visfatin levels ${ }^{[17]}$ : Concentration of visfatin was measured using ELISA method according to the manufacturer's instructions (RayBiotech Inc., USA, Cat\#: EIA-VIS-1).

Pathological studies:

The collected placentae were fixed in $10 \%$ formalin solution and sent for histopathological examination to detect any pathologic abnormalities as infarctions, atherosis, hyalinized areas and Tenny-Parkers changes.

Statistical analysis:

Quantitative variables were expressed as the mean, standard deviation and range and analyzed using unpaired t-test in parametric data (SD (standard deviation) $<50 \%$ mean) where Mann Whitney Willcoxon $U$ test was used instead of unpaired t-test in non-parametric data (SD $>50 \%$ mean).

Qualitative variables were expressed as number and percentage and analyzed using Chisquare test. Fisher exact test was used instead of chi-square when one or more expected cell $\leqslant 5$ and all hypothesis tests were two-tailed with statistical significance assessed at the $\mathrm{p}$-value $\leqslant 0.05$.

\section{Results}

The present study results did not find any significant differences in maternal age and parity between healthy control and whole preeclamptic groups or between mild and severe preeclamptic sub-groups (Table 1).

Results also showed a significant decrease in the gestational age in whole preeclamptic group than normal controls with no significant difference between mild and severe preeclamptic sub-groups. It was found a significant increase in body mass index in preeclamptic group than control group and this increase found more in severe preeclamptic sub-group than mild one (Table 1).

Results about the maternal blood pressure presented a significant increase in both systolic and diastolic blood pressure in whole preeclamptic group compared with control group and increase in both of them found more in severe preeclamptic sub-group than mild one (Table 1). 
Table 1: Clinical characteristics in control and preeclamptic groups

\begin{tabular}{|c|c|c|c|c|c|}
\hline variables & Controls $(n=30)$ & $\begin{array}{l}\text { Whole PE } \\
(\mathrm{n}=30)\end{array}$ & $\begin{array}{l}\text { Mild PE } \\
(n=13)\end{array}$ & $\begin{array}{l}\text { Sever PE } \\
(n=17)\end{array}$ & p-value \\
\hline $\begin{array}{l}\text { Maternal age } \\
\text { (years) } \\
\text { Range } \\
\text { Mean } \pm \text { SD }\end{array}$ & $\begin{array}{l}22-36 \\
27.27 \pm 3.57\end{array}$ & $\begin{array}{l}20-35 \\
27.50 \pm 3.09\end{array}$ & $\begin{array}{l}20-35 \\
27.77 \pm 3.70\end{array}$ & $\begin{array}{l}23-32 \\
27.29 \pm 2.64\end{array}$ & $\begin{array}{l}\mathrm{P} 1=0.787 \\
\mathrm{P} 2=0.667 \\
\mathrm{P} 3=0.976 \\
\mathrm{P} 4=0.684\end{array}$ \\
\hline $\begin{array}{l}\text { Parity } \\
\text { Primiparous } \\
\text { Multiparous } \\
\end{array}$ & $\begin{array}{l}11(36.66 \%) \\
19(63.33 \%) \\
\end{array}$ & $\begin{array}{l}17(56.67 \%) \\
13(43.33 \%) \\
\end{array}$ & $\begin{array}{l}6(46.15 \%) \\
7(53.85 \%) \\
\end{array}$ & $\begin{array}{l}11(64.71 \%) \\
6(35.29 \%) \\
\end{array}$ & $\begin{array}{l}\mathrm{P} 1=0.121 \\
\mathrm{P} 2=0.559 \\
\mathrm{P} 3=0.064 \\
\mathrm{P} 4=0.310\end{array}$ \\
\hline $\begin{array}{l}\text { Gestational age at delivery } \\
\text { (weeks) } \\
\text { Range } \\
\text { Mean } \pm \text { SD }\end{array}$ & $\begin{array}{l}37-41 \\
38.80 \pm 1\end{array}$ & $\begin{array}{l}34-39 \\
37.07 \pm 1.26 \\
\end{array}$ & $\begin{array}{l}35-38 \\
36.92 \pm 1.11 \\
\end{array}$ & $\begin{array}{l}34-39 \\
37.18 \pm 1.38 \\
\end{array}$ & $\begin{array}{l}\mathrm{P} 1<0.0001^{*} \\
\mathrm{P} 2<0.0001^{*} \\
\mathrm{P} 3<0.0001^{*} \\
\mathrm{P} 4=0.593\end{array}$ \\
\hline $\begin{array}{l}\text { Body mass index } \\
\left(\mathrm{kg} / \mathrm{m}^{2}\right) \\
\text { Range } \\
\text { Mean } \pm \text { SD }\end{array}$ & $\begin{array}{l}22.6-33 \\
26.38 \pm 1.99 \\
\end{array}$ & $\begin{array}{l}24.6-34 \\
28.70 \pm 2.29 \\
\end{array}$ & $\begin{array}{l}24.6-29.4 \\
26.96 \pm 1.19 \\
\end{array}$ & $\begin{array}{l}26.8-34 \\
30.03 \pm 2.04\end{array}$ & $\begin{array}{l}\mathrm{P} 1<0.0001^{*} \\
\mathrm{P} 2=0.224 \\
\mathrm{P} 3<0.0001^{*} \\
\mathrm{P} 4<0.0001^{*}\end{array}$ \\
\hline $\begin{array}{l}\text { Systolic blood pressure } \\
(\mathrm{mmHg}) \\
\text { Range } \\
\text { Mean } \pm \text { SD }\end{array}$ & $\begin{array}{l}90-130 \\
113.33 \pm 9.94\end{array}$ & $\begin{array}{l}140-210 \\
162.33 \pm 18.79\end{array}$ & $\begin{array}{l}140-150 \\
145.38 \pm 5.19\end{array}$ & $\begin{array}{l}160-210 \\
175.29 \pm 14.41\end{array}$ & $\begin{array}{l}\mathrm{P} 1<0.0001^{*} \\
\mathrm{P} 2<0.0001^{*} \\
\mathrm{P} 3<0.0001^{*} \\
\mathrm{P} 4<0.0001^{*}\end{array}$ \\
\hline $\begin{array}{l}\text { Diastolic blood pressure } \\
(\mathrm{mmHg}) \\
\text { Range } \\
\text { Mean } \pm \text { SD }\end{array}$ & $\begin{array}{l}60-85 \\
76.17 \pm 5.68\end{array}$ & $\begin{array}{l}90-120 \\
103.33 \pm 10.61\end{array}$ & $\begin{array}{l}90-99 \\
91.92 \pm 2.53\end{array}$ & $\begin{array}{l}100-120 \\
112.06 \pm 3.56\end{array}$ & $\begin{array}{l}\mathrm{P} 1<0.0001 * \\
\mathrm{P} 2<0.0001 * \\
\mathrm{P} 3<0.0001 * \\
\mathrm{P} 4<0.0001 *\end{array}$ \\
\hline
\end{tabular}

*: Statistically significant at $\mathrm{p} \leq 0.05$

$\mathrm{P} 1 ; \mathrm{p}$ value between control and whole preeclamptic groups, $\mathrm{p} 2 ; \mathrm{p}$ value between control and mild preeclamptic groups, $\mathrm{p} 3 ; \mathrm{p}$ value between control and severe preeclamptic groups, $\mathrm{p} 4 ; \mathrm{p}$ value between mild and severe preeclamptic groups.

The study results showing also a significant increase in insulin resistance value in whole preeclamptic group compared with healthy controls but no difference in insulin resistance values had been found between mild and severe preeclamptic sub-groups. Also, albumin creatinine ratio and visfatin level were increased more in whole preeclamptic group than control group and that increase was significantly much more in severe preeclamptic sub-group than mild sub-group (Table 2).

Table 2: Biochemical measurements in control and preeclamptic groups

\begin{tabular}{|c|c|c|c|c|c|}
\hline variables & Controls $(n=30)$ & $\begin{array}{l}\text { Whole PE } \\
(\mathrm{n}=30)\end{array}$ & $\begin{array}{l}\text { Mild PE } \\
(\mathrm{n}=13)\end{array}$ & $\begin{array}{l}\text { Sever PE } \\
(n=17)\end{array}$ & p-value \\
\hline $\begin{array}{l}\text { HOMA-IR } \\
\text { Range } \\
\text { Mean } \pm \text { SD }\end{array}$ & $\begin{array}{l}0.97-3.82 \\
2.06 \pm 0.68\end{array}$ & $\begin{array}{l}1.22-4.07 \\
3.23 \pm 0.72\end{array}$ & $\begin{array}{l}1.22-4.07 \\
3.05 \pm 0.81\end{array}$ & $\begin{array}{l}1.73-3.95 \\
3.36 \pm 0.64\end{array}$ & $\begin{array}{l}\mathrm{P} 1<0.0001^{*} \\
\mathrm{P} 2<0.0001^{*} \\
\mathrm{P} 3<0.0001^{*} \\
\mathrm{P} 4=0.258\end{array}$ \\
\hline $\begin{array}{l}\text { Albumin creatinine ratio } \\
(\mathrm{mg} / \mathrm{g}) \\
\text { Range }\end{array}$ & $\begin{array}{l}6.9-62.1 \\
22.47 \pm 12.52\end{array}$ & $\begin{array}{l}157.3-398.9 \\
302.30 \pm 67.59\end{array}$ & $\begin{array}{l}157.3-301.9 \\
240.68 \pm 46.98\end{array}$ & $\begin{array}{l}300-398.9 \\
349.42 \pm 34.33\end{array}$ & $\begin{array}{l}\mathrm{P} 1<0.0001^{*} \\
\mathrm{P} 2<0.0001^{*} \\
\mathrm{P} 3=0.001^{*}\end{array}$ \\
\hline
\end{tabular}




\begin{tabular}{|l|l|l|l|l|l|}
\hline Mean \pm SD & & & & & P4 $<0.0001^{*}$ \\
\hline & & & & & P1 $<0.0001^{*}$ \\
Visfatin(ng/ml) & & & & & \\
Range & $6.1-21.1$ & $10.8-89.2$ & $10.8-44.6$ & $15.2-89.2$ & P3 $<0.0001^{*}$ \\
Mean \pm SD & $12.14 \pm 3.69$ & $34.36 \pm 19.26$ & $25.71 \pm 11.54$ & $40.98 \pm 21.56$ & P4=0.042* \\
\hline
\end{tabular}

*: Statistically significant at $\mathrm{p} \leq 0.05$

$\mathrm{P} 1 ; \mathrm{p}$ value between control and whole preeclamptic groups, $\mathrm{p} 2 ; \mathrm{p}$ value between control and mild preeclamptic groups, p3; $p$ value between control and severe preeclamptic groups, $\mathrm{p} 4 ; \mathrm{p}$ value between mild and severe preeclamptic groups.

Histopathological examination of placenta controls. Only placental infarctions increase showed that infarctions, atherosis, hyalinized areas significantly in severe preeclamptic sub-group than and Tenny-Parkers changes were present greater in mild preeclamptic one (Table 3, Fig 1). preeclamptic placentae compared with healthy

Table 3: Microscopic examination of placenta in control and preeclamptic groups

\begin{tabular}{|c|c|c|c|c|c|}
\hline variables & Controls $(n=30)$ & $\begin{array}{l}\text { Whole PE } \\
(n=30)\end{array}$ & $\begin{array}{l}\text { Mild PE } \\
(n=13)\end{array}$ & $\begin{array}{l}\text { Sever PE } \\
(\mathrm{n}=17)\end{array}$ & p-value \\
\hline $\begin{array}{l}\text { Placental atherosis } \\
\text { Yes } \\
\text { No }\end{array}$ & $\begin{array}{l}2(6.66 \%) \\
28(93.33 \%)\end{array}$ & $\begin{array}{l}15(50 \%) \\
15(50 \%)\end{array}$ & $\begin{array}{l}6(46.15 \%) \\
7(53.85 \%) \\
\end{array}$ & $\begin{array}{l}9(52.94 \%) \\
8(47.06 \%) \\
\end{array}$ & $\begin{array}{l}\mathrm{P} 1<0.0001^{*} \\
\mathrm{P} 2=0.006 * \\
\mathrm{P} 3=0.001^{*} \\
\mathrm{P} 4=0.713\end{array}$ \\
\hline $\begin{array}{l}\text { Placental infarctions } \\
\text { Yes } \\
\text { No }\end{array}$ & $\begin{array}{l}3(10 \%) \\
27(90 \%)\end{array}$ & $\begin{array}{l}22(73.33 \%) \\
8(26.67 \%)\end{array}$ & $\begin{array}{l}6(46.15 \%) \\
7(53.85 \%) \\
\end{array}$ & $\begin{array}{l}16(94.12 \%) \\
1(5.88 \%)\end{array}$ & $\begin{array}{l}\text { P } 1<0.0001 * \\
\text { P2 }=0.014 * \\
\text { P3 }<0.0001 * \\
\text { P4 }=0.009 *\end{array}$ \\
\hline $\begin{array}{l}\text { Hyalinized areas } \\
\text { Yes } \\
\text { No }\end{array}$ & $\begin{array}{l}1(3.33 \%) \\
29(96.66 \%)\end{array}$ & $\begin{array}{l}9(30 \%) \\
21(70 \%)\end{array}$ & $\begin{array}{l}2(15.38 \%) \\
11(84.62 \%)\end{array}$ & $\begin{array}{l}7(41.18 \%) \\
10(58.82 \%)\end{array}$ & $\begin{array}{l}\mathrm{P} 1=0.012^{*} \\
\mathrm{P} 2=0.213 \\
\mathrm{P} 3=0.002 * \\
\mathrm{P} 4=0.229\end{array}$ \\
\hline $\begin{array}{l}\text { Tenny-Parker changes } \\
\text { Yes } \\
\text { No }\end{array}$ & $\begin{array}{l}2(6.66 \%) \\
28(93.33 \%)\end{array}$ & $\begin{array}{l}24(80 \%) \\
6(20 \%)\end{array}$ & $\begin{array}{l}10(76.92 \%) \\
3(23.08 \%)\end{array}$ & $\begin{array}{l}14(82.35 \%) \\
3(17.65 \%)\end{array}$ & $\begin{array}{l}\mathrm{P} 1<0.0001^{*} \\
\mathrm{P} 2<0.0001 * \\
\mathrm{P} 3<0.0001 * \\
\mathrm{P} 4=0.996\end{array}$ \\
\hline
\end{tabular}

*: Statistically significant at $\mathrm{p} \leq 0.05$

$\mathrm{P} 1 ; \mathrm{p}$ value between control and whole preeclamptic groups, $\mathrm{p} 2 ; \mathrm{p}$ value between control and mild preeclamptic groups, $\mathrm{p} 3 ; \mathrm{p}$ value between control and severe preeclamptic groups, $\mathrm{p} 4 ; \mathrm{p}$ value between mild and severe preeclamptic groups. 


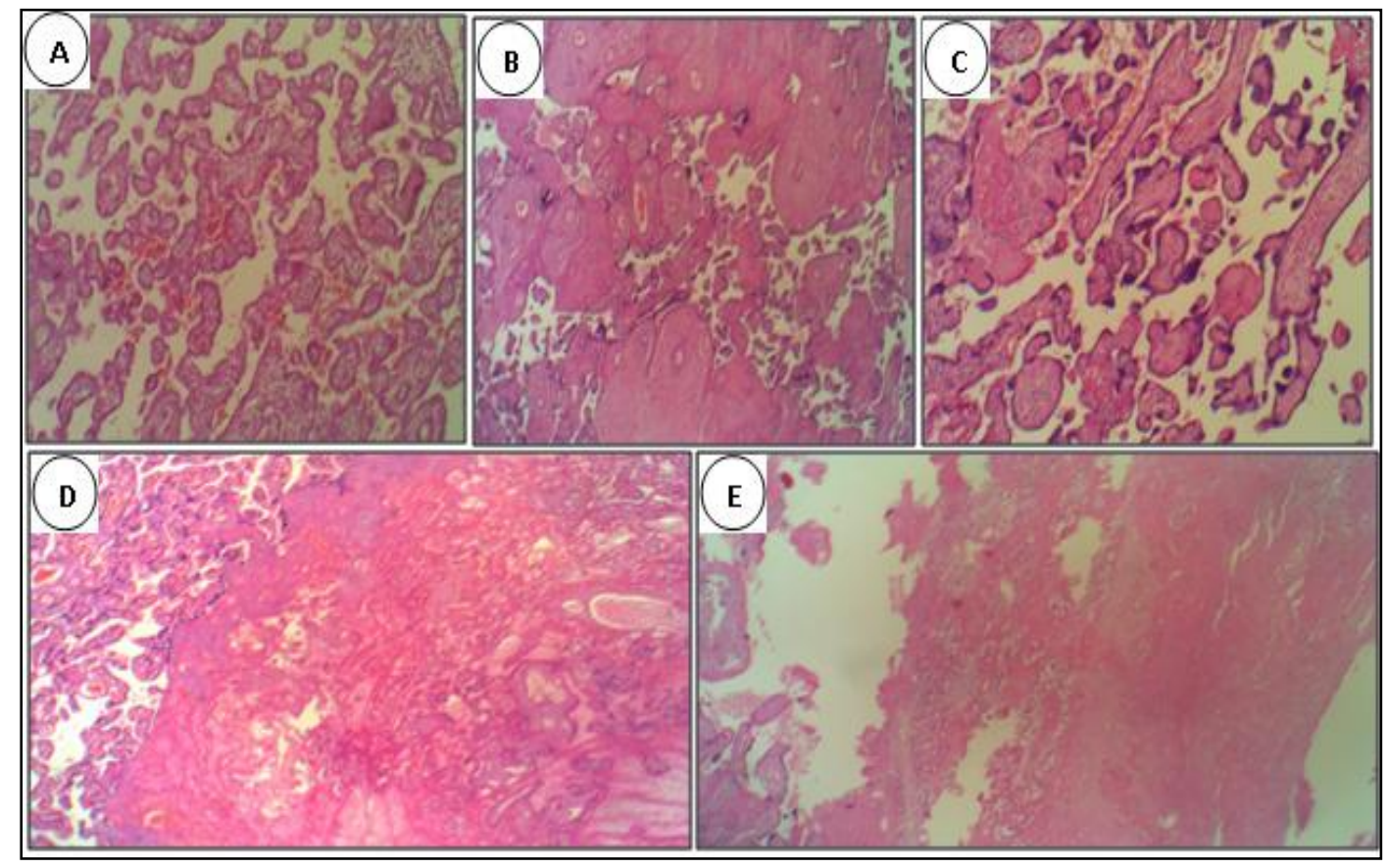

Figure 1: Microscopic examination of placenta: A (Normal placenta), B (Atherosis), C (Tenny-Parker changes), $D$ (Infarctions) and E (Hyalinized areas)

Data obtained from correlation analysis found a significant positive correlation between visfatin level versus systolic blood pressure $(\mathrm{r}=0.536, \mathrm{p}=$ $0.002)$ and diastolic blood pressure $(r=0.469, \mathrm{p}=$ $0.009)$ and also a significant negative correlation between serum visfatin level versus HOMA-IR $(\mathrm{r}=$ $-0.375, p=0.041$ ), but no significant correlation was found between visfatin levels versus body mass index (Fig 2).

The present study did not find any significant correlation between maternal serum levels of visfatin versus histopathological changes of placentae among pregnant women with preeclampsia.

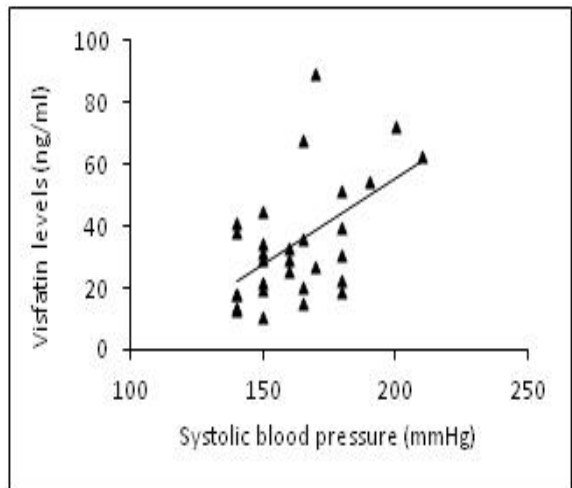

Subfigure A.

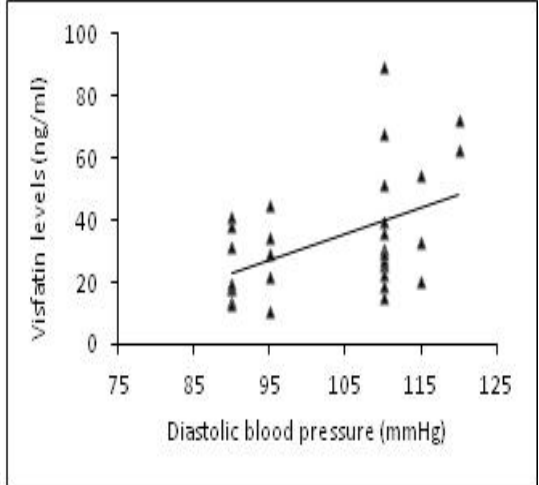

Subfigure B.

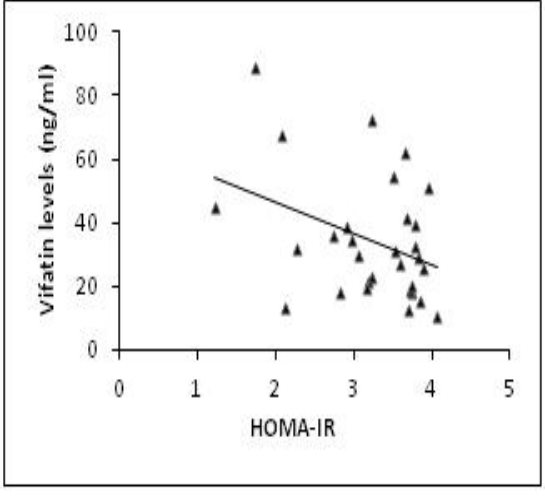

Subfigure $\mathbf{C}$.

Figure 2: Correlation between visfatin level versus systolic blood pressure, diastolic blood pressure and HOMAIR among preeclamptic women.

A.Correlation between visfatin levels and systolic blood pressure among preeclamptic women. $(\mathrm{r}=0.536, \mathrm{p}=0.002)$

B.Correlation between visfatin levels and diatolic blood pressure among preeclamptic women. $(\mathrm{r}=0.469, \mathrm{p}=0.009)$

C.Correlation between visfatin levels and HOMA-IR among preeclamptic women. $(r=-0.375, p=0.041)$ 


\section{Discussion}

The aim of the present study was based on two points: firstly, identification of adipocytokines in preeclampsia and this point was achieved by determination of maternal serum levels of visfatin in normotensive and preeclamptic pregnant women and possible correlations of visfatin to measured insulin resistance and body mass index. Secondly, possible correlation between adipocytokines and histopathologic changes in preeclamptic placentae and this point was achieved by microscopic examination of placentae and study the relation between maternal serum levels of visfatin versus some pathologic abnormalities in placentae of pregnant women complicated with preeclampsia.

Changes in endothelial function and vasoactive agents have been proposed as possible pathogenic mechanisms of preeclampsia. [18] The insulin resistance syndrome has been linked to this alteration, and hyperinsulinemia promotes oxidative stress, which is related with inactivation of nitric oxide and endothelial dysfunction. ${ }^{[19]}$ There are increasing data supporting the role of insulin resistance in preeclampsia [20], although this evidence has not been seen in all studies [21]. Our research confirms the increased insulin resistance in preeclamptic women and these results in agreement with those of Stefanović et al. ${ }^{[22]}$ Masuyama et al. [23] also partially in agreement with our results; they found an increase in HOMA-IR in overweight patients with late-onset preeclampsia.

Since placental oxidative stress is regarded as an intermediate event in the pathogenesis of preeclampsia ${ }^{[24]}$, several studies have addressed the molecular mechanisms by which oxidative stress might lead to insulin resistance. In vitro, Reactive oxygen species (ROS) and oxidative stress lead to activation of multiple serine/threonine kinase signaling cascades, these activated kinases can act on a number of potential targets in the insulin signaling pathway, including the insulin receptor and the family of Insulin receptor substrate (IRS) proteins ${ }^{[25]}$.

Visfatin, another adipocytokine, is highly expressed in visceral as compared to subcutaneous adipose tissue that promotes adipogenesis. ${ }^{[26]}$ The presence of visfatin transcript in human fetal membrane has been reported ${ }^{[27]}$.
In the current study, results showed a significant increase in visfatin level in preeclamptic women compared with normal pregnant women. These results were in agreement with those of Zorba et al. ${ }^{[28]}$ Study results found also visfatin level increased significantly in severe preeclamptic group than mild preeclamptic group and these findings were in agreement with those of Zulfikaroglu et al. [9] Unlike our results about visfatin levels, $\mathrm{Hu}$ et al ${ }^{[10]}$ showed a significant decrease in visfatin levels in preeclamptic women.

Reasons for these conflicting results are unclear at present but it was reported that differences in specificity of the visfatin immunoassays utilized might potentially contribute to inconsistencies observed in preeclamptic women [29].

In second half of pregnancies, a physiological insulin resistance which is characterized by hyperinsulinemia, glucose intolerance and lipid abnormalities has been documented [30]. Because dysregulation of visfatin is found in insulin resistance, visfatin may be a predisposing factor in preeclampsia ${ }^{[31]}$. Fasshauer et al. found that visfatin levels were significantly elevated in pregnancies with IUGR in third trimester ${ }^{[32]}$. Also, Adali et al. [33] reported that visfatin and leptin levels of pregnant women with preeclampsia with abnormal Doppler velocimetry were significantly higher than those with normal velocimetry, in all these studies, visfatin was found to be a part of physiological feed-back mechanism improving insulin signaling in insulin resistance-associated diseases as obesity, pregnancy-related complications and type-2 diabetes mellitus.

Regarding microscopic examination of placentae, results found a significant increase in placental atherosis in preeclamptic group than control group and these results were in agreement with those of Artico et al. ${ }^{[34]}$ It was suggested that oxidative stress could be a driving force also in the development of acute atherosis, possibly activating the phospholipase A2 (PLA2) activity in preeclamptic decidual tissue ${ }^{[35]}$.

Results also found that infarctions increased in preeclamptic group than control group and these results were in agreement with those of Artico et al. [34] Zeek et al. [36] reported that presence of placental infarctions mainly due to complete 
interference with their blood supply in the decidua or in the local state by thrombosis of a spiral arteriole or a retroplacental haemorrhage.

Concerning Tenny-parker changes (syncytial knots); results recorded that syncytial knots increased in preeclamptic group than control group and these results were in agreement with those of Artico et al. ${ }^{[34]}$ Hypertension in pregnancy causes placental hypoxia leading to loss of large number of parenchymal cells, which causes appearance of syncytial knots and synthesis of fibrous tissue in their place ${ }^{[37]}$.

Regarding hyalinized areas, results of histopatholopical examination of placenta recorded also a significant increase in preeclamptic group than control group and these results agreed with those of Majumdar et al. ${ }^{[38]}$

Correlation analysis presented a significant negative correlation between maternal levels of visfatin and HOMA-IR and these findings agreed with those of Fasshauer et al. ${ }^{\text {[39] }}$

Visfatin improves insulin receptor sensitivity [40] and owing to its action as nicotinamide phosphoribosyltransferase (Nampt) increases synthesis of NAD and nicotinamide mononucleotide, enhancing pancreatic $\beta$ cells and improving insulin production and secretion ${ }^{[26]}$.

Regarding correlation between visfatin levels and blood pressure, the present study showed that maternal visfatin level had a significant positive correlation with blood pressure (systolic and diastolic) and these results agreed with those of Zorba et al. ${ }^{[28]}$. In the study of Shutte et al, a significant correlation was found between visfatin and mean blood pressure and they concluded that visfatin seems to direct its effects onto the vascular system possibly by means of mechanisms such as inflammation and vasoconstriction ${ }^{[41]}$.

Concerning correlation between visfatin levels and body mass index, study results showed no correlation between them, however this adipokine correlate strongly with the amount of visceral fat in humans ${ }^{[42]}$. This may be supported by a recent animal study showed that visfatin is a myokine, secreted from skeletal muscle cells in a hypertensive rat model ${ }^{[43]}$.

The evidence that the growth of fat mass is associated with an accumulation of adipose tissue macrophages and T-lyphocytes has raised the hypothesis that the development of an inflammatory process within the growing fat mass is a primary event involved in the genesis of systemic metabolic and vascular alterations ${ }^{[44]}$. The fact that adipose tissue releases a wide range of adipokines, growth factors, enzymes and enzyme substrates linked to vascular injury provides a plausible explanation for the role of fat in vascular disease. Visfatin among many other products which are TNF $\alpha$, leptin, resistin, IL-1, IL-6, IL-8, and IL-18, chimerin, serum amyloid A, MCP-1, macrophage inhibitory factor (MIF), aortic carboxypeptidase, heparinbinding epidermal growth factor-like growth factor(HB-EGF), vascular endothelial growth factor (VEGF), transforming growth factor-beta (TGF), angiotensinogen, cathepsin S, estradiol, cortisol, mineralocorticoid releasing factor, and calcitonin peptides are probable fat-derived prothrombotic, proinflammatory, and proatherosclerotic agents acting in an endocrine and/or paracrine manner. Other adipocyte products such as adiponectin, and interleukin-10 exert an antiatherogenic effect ${ }^{[45]}$. The results of our previous study revealed that preeclamptic women were more insulin resistant with a significant decrease in adiponectin level compared with healthy controls ${ }^{[46]}$.

This was also in accordance with published data showing that body mass index is only related to visfatin in men, but not in women [47]. LopezBermejo et al. ${ }^{[48]}$, Dogru et al. ${ }^{[49]}$ reported absence of correlation between plasma visfatin and body mass index and explained this finding by the differential regulation of visfatin expression in the different adipose depots. Hence, the increase in visceral adipose tissue visfatin with obesity may be balanced by the decrease in subcutaneous adipose tissue visfatin, such that plasma visfatin is not affected by increasing body mass index.

\section{Conclusions}

Insulin resistance may be one of the casual pathways of preeclampsia, so improving insulin sensitivity in high risk women before and during early pregnancy may reduce risk of preeclampsia. Visfatin might be part of a feedback mechanism improving insulin sensitivity in preeclamptic women. Hypervisfatinemia may be one of the possible etiologies of preeclampsia, so measuring of 
this adipokine may be useful for prognosis and assessment of the severity of disease.

Preeclamptic placentae underwent definite histopathological changes seemed to be the result of insufficiency of placenta in preeclampsia.

\section{References}

1 Report of the National High Blood Pressure Education Program Working Group on High Blood Pressure in Pregnancy. Am J Obstet Gynecol 2000; 183(1): S1-S22 [PMID: 10920346]

2 Sibai B, Dekker G , Kupferminc M . Preeclampsia. Lancet 2005; 365 (9461): 78599.PMID: 15733721

3 Huppertz B. The anatomy of the normal placenta. J Clin Pathol 2008; 61(12): 12961302 [PMID: 18755720 DOI: 10.1136/jcp.2008.055277]

4 Rodie VA, Freeman DJ, Sattar N, Greer IA. Pre-eclampsia and cardiovascular disease: metabolic syndrome of pregnancy? Atherosclerosis 2004; 175(2): 189-202 DOI: 10.1016/j.atherosclerosis.2004.01.038

5 Ryan EA, Enns L. Role of gestational hormones in the induction of insulin resistance. J Clin Endocrinol Metab 1988; 67(2): 341347 DOI: $10.1210 /$ jcem-67-2-341

6 Catalano PM, Roman-Drago NM, Amini SB, Sims EA. Longitudinal changes in body composition and energy balance in lean women with normal and abnormal glucose tolerance during pregnancy. Am J Obstet Gynecol 1998; 179(1): 156-165 DOI: 10.1016/s0002-9378(98)70267-4

7 Chen MP, Chung FM, Chang DM, Tsai JC, Huang HF, Shin SJ, Lee YJ. Elevated plasma level of visfatin/pre-B cell colony-enhancing factor in patients with type 2 diabetes mellitus. J Clin Endocrinol Metab 2006; 91(1):295-9. PMID: 16234302

8 Haugen F, Ranheim T, Harsem NK, Lips E, Staff AC, Drevon CA. Increased plasma levels of adipokines in preeclampsia: relationship to placenta and adipose tissue gene expression. Am J Physiol Endocrinol Metab 2006; 290(2): E326-333 [PMID: 16144822 DOI: 10.1152/ajpendo.00020.2005]
9 Zulfikaroglu E, Isman F, Payasli A, Kilic S, Kucur M, Danisman N. Plasma visfatin levels in preeclamptic and normal pregnancies. Arch Gynecol Obstet 2010; 281(6): 995-998 [PMID: 19639329 DOI: 10.1007/s00404-009-1192-z]

$10 \mathrm{Hu}$ W, Wang Z, Wang H, Huang H, Dong M. Serum visfatin levels in late pregnancy and pre-eclampsia. Acta Obstet Gynecol Scand 2008; 87(4): 413-418 [PMID: 18382866 DOI: $\underline{10.1080 / 00016340801976012]}$

11 Chavan VU, Sayyed AK, Durgawale PP, Sontakke AV, Nilakhe SD. Practical Aspects of Calculation, Expression and Interpretation of Urine Albumin Measurement. NJIRM 2011; 2(1):29-34.

12 Lamb E, Newman DJ, Price CP. Kidney function tests. In: Buritis CA, Ashwood ER, Burn DE. Teitz textbook of clinical chemistry and molecular diagnostics. 4 th edition. WB Sauders, Philadelphia 2006, pp. 795-835.

13 Bernard A, Lauwerys R. Latex immunoassay of urine albumin. J Clin Chem Biochem 1983; 21(1):25-30.PMID: 6854217

14 Matthews DR, Hosker JP, Rudenski AS, Naylor BA, Treacher DF, Turner RC. Homeostasis model assessment: insulin resistance and beta-cell function from fasting plasma glucose and insulin concentrations in man. Diabetologia 1985; 28(7): 412-419 [PMID: 3899825]

15 Tietz NW. Clinical Guide to laboratory Tests. 3rdedition. WB Sauders Company, Philadelphia 1995, pp. 268-9.

16 Starr JI, Mako ME, Juhn D, Rubenstein AH. Measurement of serum proinsulin-like material: cross-reactivity of porcine and human proinsulin in the insulin radioimmunoassay. $\boldsymbol{J}$ Lab Clin Med 1978; 91(4): 683-692 [PMID: 641392]

17 Hug C, Lodish HF. Medicine. Visfatin: a new adipokine. Science 2005; 307(5708): 366-367 [PMID: 15604359 DOI: 10.1126/science.1106933]

18 Roberts JM, Redman CW. Pre-eclampsia: more than pregnancy-induced hypertension. Lancet 1993; 341(8858): 1447-1451 [PMID: 8099148 DOI: $\underline{10.1016 / 0140-6736(93) 90889-}$ o] 
19 Arcaro G, Cretti A, Balzano S, Lechi A, Muggeo M, Bonora E, Bonadonna RC. Insulin causes endothelial dysfunction in humans: sites and mechanisms. Circulation 2002; 105(5): 576-582 DOI: $\underline{10.1161 / \mathrm{hc} 0502.103333}$

20 Seely EW, Solomon CG. Insulin resistance and its potential role in pregnancy-induced hypertension. J Clin Endocrinol Metab 2003; 88(6): 2393-2398 DOI: 10.1210/jc.2003$\underline{030241}$

21 Roberts RN, Henriksen JE, Hadden DR. Insulin sensitivity in pre-eclampsia. $\boldsymbol{B r} \boldsymbol{J}$ Obstet Gynaecol 1998; 105(10): $1095-1100$ [PMID: 9800933]

22 Stefanovic M, Vukomanovic P, Milosavljevic M, Kutlesic R, Popovic J, Tubic-Pavlovic A. Insulin resistance and $\mathrm{C}$-reactive protein in preeclampsia. Bosn J Basic Med Sci 2009; 9(3): 235-238 DOI:

$\underline{10.17305 / \mathrm{bjbms} .2009 .2813}$

23 Masuyama H, Inoue S, Hiramatsu Y. Retinolbinding protein 4 and insulin resistance in preeclampsia. Endocr $\boldsymbol{J}$ 2011; 58(1): 47-53 [PMID: 21173508]

24 Brosens JJ, Pijnenborg R, Brosens IA. The myometrial junctional zone spiral arteries in normal and abnormal pregnancies: a review of the literature. Am J Obstet Gynecol 2002; 187(5): 1416-1423 DOI: 10.1067/mob.2002.127305

25 Evans JL, Goldfine ID, Maddux BA, Grodsky GM. Are oxidative stress-activated signaling pathways mediators of insulin resistance and beta-cell dysfunction? Diabetes 2003; 52(1): 18 DOI: $10.2337 /$ diabetes.52.1.1

26 Fukuhara A, Matsuda M, Nishizawa M, Segawa K, Tanaka M, Kishimoto K, Matsuki Y, Murakami M, Ichisaka T, Murakami H, Watanabe E, Takagi T, Akiyoshi M, Ohtsubo T, Kihara S, Yamashita S, Makishima M, Funahashi T, Yamanaka S, Hiramatsu R, Matsuzawa Y, Shimomura I. Visfatin: a protein secreted by visceral fat that mimics the effects of insulin. Science 2005; 307(5708): 426-430 DOI: $10.1126 /$ science. 1097243

27 Morgan SA, Bringolf JB, Seidel ER. Visfatin expression is elevated in normal human pregnancy. Peptides 2008; 29(8): 1382-1389 DOI: $\underline{10.1016 / \text { j.peptides.2008.04.010 }}$
28 Zorba E, Vavilis D, Venetis CA, Zournatzi V, Kellartzis D, Tarlatzis BC. Visfatin serum levels are increased in women with preeclampsia: a case-control study. J Matern Fetal Neonatal Med 2012; 25(9): 1668-1673 DOI: $10.3109 / 14767058.2012 .657275$

29 Korner A, Garten A, Bluher M, Tauscher R, Kratzsch J, Kiess W. Molecular characteristics of serum visfatin and differential detection by immunoassays. J Clin Endocrinol Metab 2007; 92(12): 4783-4791 DOI: $\underline{10.1210 / j c .2007-}$ 1304

30 Mazaki-Tovi S, Romero R, Kusanovic JR, Vaisbuch E, Erez O, Than NG, Chaiworapongsa T, Nhan-Chang CL, Pacora P, Gotsch F, Yeo L, Edwin SS, Hassan SS, and Mittal P. Maternal visfatin concentration in normal pregnancy. J Perinat Med 2009; 37(3):206-17. PMID: 19284295

31 Jian WX, Luo TH, Gu YY, Zhang HL, Zheng S, Dai M, Han JF, Zhao Y, Li G, Luo M. The visfatin gene is associated with glucose and lipid metabolism in a Chinese population. Diabet Med 2006; 23(9): 967-973 DOI: 10.1111/j.1464-5491.2006.01909.x

32 Fasshauer M, Bluher M, Stumvoll M, Tonessen P, Faber R, Stepan H. Differential regulation of visfatin and adiponectin in pregnancies with normal and abnormal placental function. Clin Endocrinol (Oxf) 2007; 66(3): 434-439 DOI: 10.1111/j.13652265.2007.02751.x

33 Adali E, Yildizhan R, Kolusari A, Kurdoglu M, Bugdayci G, Sahin HG, Kamaci M. Increased visfatin and leptin in pregnancies complicated by pre-eclampsia. J Matern Fetal Neonatal Med 2009; 22(10): 873-879 [PMID: 19488934 DOI: $10.1080 / 14767050902994622]$

34 Artico LG, Madi JM, Godoy AE, Coelho CP, Rombaldi RL, Artico GR. [Histopathological changes in human placentas related to hypertensive disorders]. Rev Bras Ginecol Obstet 2009; 31(1): 10-16 [PMID: 19347223]

35 Staff AC, Ranheim T, Halvorsen B. Augmented PLA2 activity in pre-eclamptic decidual tissue--a key player in the pathophysiology of 'acute atherosis' in preeclampsia? Placenta 2003; 24(10): 965-973 [PMID: 14580379] 
36 Zeek PM, Assali NS. Vascular changes in the decidua associated with eclamptogenic toxemia of pregnancy. Am J Clin Pathol 1950; 20(12): $\quad$ 1099-1109 DOI: 10.1093/ajcp/20.12.1099

37 Ashfaq M, Janjua MZ, Channa MA. Effect of gestational diabetes and maternal hypertension on gross morphology of placenta. J Ayub Med Coll Abbottabad 2005; 17(1): 44-47

38 Majumdar S, Dasgupta H, Bhattacharya K, Bhattacharya A. A Study of Placenta in Normal and Hypertensive Pregnancies. J Anat Soc India 2005; 54 (2): 1-9.

39 Fasshauer M, Waldeyer T, Seeger J, Schrey S, Ebert T, Kratzsch J, Lossner U, Bluher M, Stumvoll M, Faber R, Stepan H. Serum levels of the adipokine visfatin are increased in preeclampsia. Clinical Endocrinology 2008; 69(1):69-73. PMID: 18034779

40 Luk T, Malam Z, Marshall JC. Pre-B cell colony-enhancing factor (PBEF)/visfatin: a novel mediator of innate immunity. $J$ Leukoc Biol 2008; 83(4): 804-816 [PMID: 18252866 DOI: $10.1189 / \mathrm{jlb} .0807581]$

41 Schutte AE, Huisman HW, Schutte R, van Rooyen JM, Malan L, Fourie CM, Malan NT. Adipokines and cardiometabolic function: How are they interlinked? Regul Pept 2010; 164(2-3): 133-138 DOI: 10.1016/j.regpep.2010.06.008

42 Ramsay JE, Ferrell WR, Crawford L, Wallace AM, Greer IA, Sattar N. Maternal obesity is associated with dysregulation of metabolic, vascular, and inflammatory pathways. J Clin Endocrinol Metab 2002; 87(9): 4231-4237 DOI: $10.1210 /$ jc. 2002-020311

43 Wang P, Du H, Zhang RY, Guan YF, Xu TY, $\mathrm{Xu}$ QY, Su DF, Miao CY. Circulating and local visfatin/Nampt/PBEF levels in spontaneously hypertensive rats, stroke-prone spontaneously hypertensive rats and WistarKyoto rats. J Physiol Sci 2010; 60(5): 317-324 DOI: $10.1007 / \mathrm{s} 12576-010-0103-1$

44 Zhang $\mathrm{H}$, Zhang C. Regulation of Microvascular Function by Adipose Tissue in Obesity and Type 2 Diabetes: Evidence of an Adipose-Vascular Loop. Am J Biomed Sci 2009; 1(2): 133 [PMID: 20098632 PMCID: PMC2809393]

45 Marcus Y, Stern N. Fat cell-derived modulators of vascular cell pathophysiology: the list keeps growing. J Cardiometab Syndr 2006; 1(2): 121-124 [PMID: 17679816]

46 Megahed M.A, Dawoud S.M , El-Sarha A.I ,Fayed M.A and Ahmed M.I. Maternal serum level of adiponectin and macroscopic changes of placentae in preeclampsia. 2018,10(2),72-81. Doi: 10.5099/aj180200072

47 Berndt J, Kloting N, Kralisch S, Kovacs P, Fasshauer M, Schon MR, Stumvoll M, Bluher M. Plasma visfatin concentrations and fat depot-specific mRNA expression in humans. Diabetes 2005; 54(10): 2911-2916 [PMID: 16186392 DOI: $10.2337 /$ diabetes.54.10.2911]

48 Lopez-Bermejo A, Chico-Julia B, FernandezBalsells M, Recasens M, Esteve E, Casamitjana R, Ricart W, Fernandez-Real JM. Serum visfatin increases with progressive betacell deterioration. Diabetes 2006; 55(10): 2871-2875 [PMID: 17003355 DOI: $10.2337 / \mathrm{db} 06-0259]$

49 Dogru T, Sonmez A, Tasci I, Bozoglu E, Yilmaz MI, Genc H, Erdem G, Gok M, Bingol $\mathrm{N}$, Kilic S, Ozgurtas T, Bingol S. Plasma visfatin levels in patients with newly diagnosed and untreated type 2 diabetes mellitus and impaired glucose tolerance. Diabetes Res Clin Pract 2007; 76(1): 24-29 [PMID: 16956691 DOI: 10.1016/j.diabres.2006.07.031] 